\title{
Biodiversity of macrofungi in Yenepoya Campus, Southwest India
}

\author{
Karun NC ${ }^{1}$, Bhagya $\mathrm{BS}^{2}$ and Sridhar $\mathrm{KR}^{1}$ *
}

\author{
${ }^{1}$ Department of Biosciences, Mangalore University, Mangalagangotri, Mangalore 574 199, Karnataka, India \\ ${ }^{2}$ Centre for Environmental Studies, Yenepoya (Deemed to be University), Derlakatte, Mangalore 575018 , \\ Karnataka, India
}

Karun NC, Bhagya BS, Sridhar KR 2018 - Biodiversity of macrofungi in Yenepoya Campus, Southwest India. Microbial Biosystems 3(1), 1-11.

\begin{abstract}
Public and private institutions usually possess land space for buildings, play grounds, gardens, avenues and natural vegetation. Such landscapes possess diverse flora, fauna and microbiota. Inventory of biodiversity in the vicinity constitutes first step to follow the status of habitat based on diversity, carrying capacity and further steps for conservation or rehabilitation. The current study assessed macrofungal diversity in the Yenepoya Campus of southwest India in continuation of assessment of flora and fauna. This preliminary inventory was carried out in 10 habitats (three plantations, bamboo thickets, gardens, acacia groves, avenue trees, lawns, dumped wood and termite mounds), which yielded 40 species of macrofungi belonging to 31 genera. Among them, twelve species were edible, twelve species were medicinal, two species were ectomycorrhizal and finally one species was entomophagous. Substrates supporting macrofungi include soil (particolous), humus (humicolous), woody debris (lignicolous) and insects (entomophagous). Results showed an abundance of five species (Amylosprous campbellii, Daldinia concentrica, Lenzites betulina, Marasmiellus stenophyllus and Schizophyllum commune), 13 others were common and 22 species were occasional. In addition to flora and fauna, inventory of saprophytic macrofungi (involved in recycling the organic matter) occurring in an institution surroundings help designating the habitat as healthy or regenerated or impoverished to follow appropriate measures to maintain the status quo, rehabilitation and conservation. This study suggests possibilities of domestication and utilization of several edible, medicinal and ectomycorrhizal fungi in this area.
\end{abstract}

Key words- Biodiversity, mushrooms, lateritic soil, leaf litter, woody litter.

\section{Introduction}

Biodiversity issues have gained importance after the Earth Summit 'Convention on Biological Diversity' (CBD) in Rio de Janeiro during June 1992. However, owing to the least concern on fungi, they have been designated as 'Orphans of Rio' (Minter 2010). In spite of such an impediment, interest on fungi as the 'fifth kingdom' has exploded globally to project their importance similar to flora and fauna. To fill the gap of CBD, the International Society for Fungal Conservation was set up to address several issues related to fungi (www.fungalconservation.org).

Macrofungi or mushrooms are a fascinating group of visible fungi attracting the attention worldwide due to their diversity, morphology (shape and color) and economic value (nutrition, medicine and biomolecules). Most of them are epigeic, however some are hypogeic (e.g. truffles) 
and relay on animals for dispersal. Based on the plant-fungus ratio, Mueller et al. (2007) have predicted global macrofungi ranging between 53,000 and 110,000 species. Being saprotrophs, macrofungi grow on a wide range of substrates mainly soil, wood and leaf litter. Many of them develop a mutualistic association with roots of tree species as ectomycorrhizae. Owing to the economic importance of macrofungi in human nutrition, medicine and forestry, research has been intensified towards their diversity and utilization.

Diverse landscapes of the Western Ghats and west coast of India (e.g. grasslands; forests: shola, deciduous, moist-dry deciduous, evergreen, semi-evergreen, lateritic scrub jungles, mangroves; coastal sand dunes) provide suitable climatic conditions as well as substrates for growth and perpetuation of macrofungi. Checklists of the Western Ghats region of India include 616 species and 178 species of agarics in Kerala and Maharashtra states, respectively (Farook et al. 2013; Senthilarasu 2014). Mohanan (2011) has described up to 550 species of macrofungi from different regions of the Kerala State. Surveys in semi-evergreen and moist-deciduous forests of Karnataka yielded up to 315 species of macrofungi (Swapna et al. 2008). Checklist from the Western Ghats region of Maharashtra State documented 256 species of Aphyllophorales (Ranadive et al. 2011). On the other hand, Karun and Sridhar (2016) recorded 157 species of macrofungi from different forests of the Western Ghats of Karnataka. Up to 79 macrofungi (range 15-36 species) were recovered from the plantations, botanical garden and arboretum of the lateritic region of southwest Karnataka (Karun and Sridhar 2014; Pavithra et al. 2016). The coastal sand dunes and mangroves of Karnataka also consist of 64 and 46 macrofungi, respectively (Ghate and Sridhar 2016a, 2016b). There is a tendency of gradual decrease in the number of macrofungi from the Western Ghats forests towards the west coast (Western Ghats $>$ coastal scrub jungles $>$ coastal sand dunes $>$ mangroves) (Karun and Sridhar 2014; Sridhar 2018). Even though the scrub jungles possess relatively less number of macrofungi than the Western Ghats, the old growth forests consist of diverse ectomycorrhizal, edible and medicinal fungi (Karun and Sridhar 2014).

Many institutions have shown interest to protect their vicinity and evaluate the extent of biodiversity. Some of them besides planting avenue trees use their land space to establish medicinal garden and arboretum to cultivate native as well as rare and endangered tree species. Such landscapes after a couple of decades produce a substantial amount of plant debris (leaf litter, woody litter, bark and inflorescence). The secondary product is the major substrate for growth and perpetuation of macrofungi. Besides, several tree species in scrub jungles are known to support ectomycorrhizal fungi (Pavithra et al. 2015, 2017). The Yenepoya (deemed to be University) (YU) in the coastal region of Karnataka showed concern to protect its greenery and initiated biodiversity auditing (e.g. plants, birds, butterflies and insects). At the outset several macrofungi were seen during the wet season on the campus, hence this inventory documents macrofungi on different habitats and substrates of the YU campus.

\section{Materials and Methods}

The macrofungal survey was carried out in the landscape of YU Campus spanning about 15.2 ha $\left(12.81^{\circ} \mathrm{N}, 74.88^{\circ} \mathrm{E} ; 22 \mathrm{~m}\right.$ asl). The survey was confined to fortnightly intervals up to six months during monsoon and a post-monsoon period (June-November, 2016). On each sampling date, air (in the shade) and soil temperatures (at $10 \mathrm{~cm}$ depth) in five locations were measured by a mercury thermometer (N.S. Dimple Thermometers, New Delhi, India; Model \# 17876; $\pm 0.2^{\circ} \mathrm{C}$ ). Similarly, humidity of air was recorded by Mextech Digital Thermohygrometer (Mumbai, India; Model \# TM-1; accuracy, $\pm 1 \%$ ).

Some of the habitats suitable for the growth of macrofungi include bamboo thickets (Bambusa burmanica), Acacia groves, horticultural gardens, medicinal garden, plantations (Areca, banana and coconut), lawns and avenue trees. Besides, lateritic soil, humus, organic debris (woody litter, twig litter, bark litter, spathode of Areca, leaf litter, pods of Acacia and 
grass shreds), stubs/stumps of trees, dumped logs, standing dead trees and termite mounds are the potential substrates for growth of macrofungi. Each fungus was examined on first and subsequent sampling based on macroscopic and microscopic examinations (Olympus CX41RF; magnification, 1000X) using the diagnostic keys (Pegler 1990; Jordan 2004; Phillips 2006; Cannon and Kirk 2007; Mohanan 2011; Buczacki 2012; Tibuhwa 2012).

\section{Results and Discussion}

During the study period, air and soil temperatures ranged from $25.4-30.4^{\circ} \mathrm{C}$ and 25.5 $27.5^{\circ} \mathrm{C}$, respectively (Table 1). Humidity was higher during the first three months (June-August: 70-80.7\%) than the latter months (September-November: 67.3-69.3\%). Temperature and humidity regimes during the monsoon and post-monsoon period were ideal for the growth of macrofungi in different habitats as well as substrates. September month yielded the highest of 23 species followed by August (21 spp.), while in the first and last two months, fungal richness varied between 10 and 12 species (Fig. 1). A similar trend of species richness was seen in the Western Ghat forests of Karnataka (Karun and Sridhar 2014).

Table 1 Temperature and humidity during macrofungal survey in the Yenepoya Campus (JuneNovember, 2016) ( $n=5$; mean \pm SD).

\begin{tabular}{lccc}
\hline & Humidity (\%) & \multicolumn{2}{c}{ Temperature $\left({ }^{\circ} \mathbf{C}\right)$} \\
\cline { 3 - 4 } & & Air & Soil \\
\hline June 11 & $77.3 \pm 2.87$ & $25.4 \pm 0.36$ & $26.3 \pm 0.25$ \\
June 25 & $70.6 \pm 9.45$ & $27.4 \pm 1.15$ & $25.8 \pm 0.31$ \\
July 16 & $70.0 \pm 9.88$ & $30.3 \pm 0.21$ & $26.2 \pm 0.76$ \\
July 29 & $73.7 \pm 4.16$ & $26.3 \pm 0.31$ & $26.8 \pm 0.76$ \\
August 18 & $75.3 \pm 4.93$ & $27.6 \pm 0.64$ & $26.4 \pm 0.36$ \\
August 31 & $80.7 \pm 4.93$ & $26.9 \pm 1.02$ & $25.5 \pm 0.50$ \\
September 16 & $67.3 \pm 1.16$ & $30.1 \pm 0.67$ & $27.5 \pm 1.32$ \\
September 26 & $68.0 \pm 2.00$ & $30.4 \pm 2.32$ & $27.2 \pm 0.76$ \\
October 18 & $68.0 \pm 1.00$ & $28.3 \pm 0.45$ & $26.3 \pm 0.25$ \\
October 27 & $69.3 \pm 0.58$ & $28.8 \pm 1.57$ & $27.0 \pm 0.50$ \\
November 16 & $68.0 \pm 1.00$ & $28.6 \pm 0.36$ & $27.2 \pm 0.31$ \\
\hline
\end{tabular}

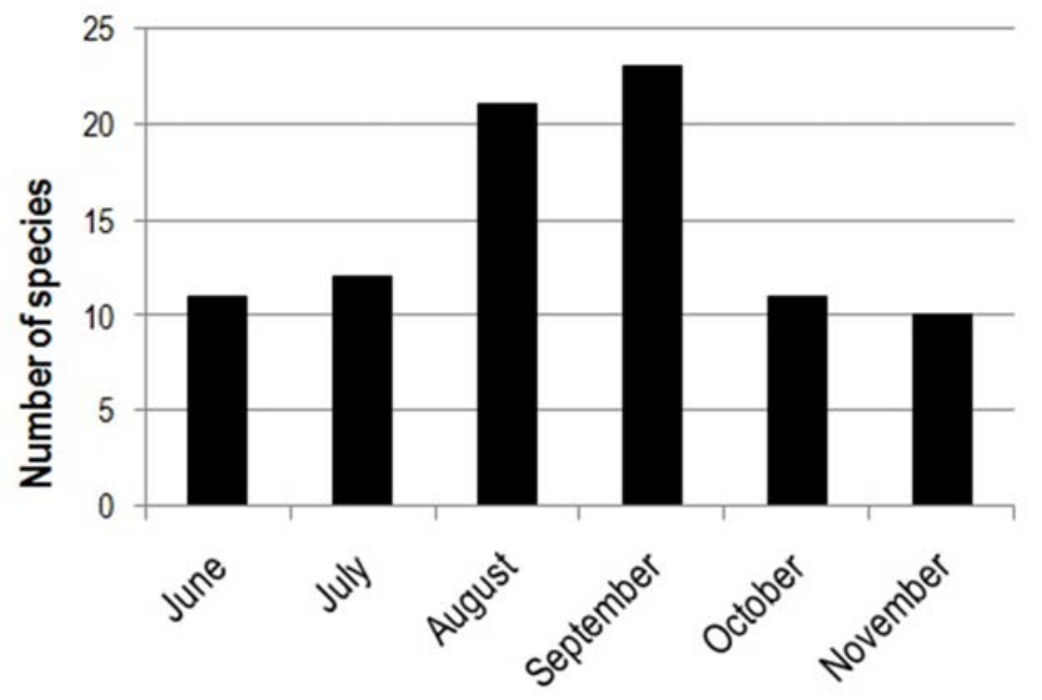

Fig. 1- Occurrence of macrofungi in different months during monsoon and post-monsoon seasons. 
List of macrofungi, habitats, substrates, a period of occurrence, the extent of occurrence and salient features are given in Table 2. A total of 40 species belonging to 31 genera were recorded (Figs. 2 and 3). Five species were most abundant; those species include Amylosprous campbellii, Daldinia concentrica, Lenzites betulina, Marasmiellus stenophyllus and Schizophyllum commune. Except for $M$. stenophyllus, rest of them has been considered as medicinal. Twelve species were edible and medicinal, while only two species were ectomycorrhizal (Fig. 4). The overlapping fungi were four species as edible and medicinal ( $A$. campbellii, Lentinus dicholamellatus, L. squarrosulus and Termitomyces fuliginosus); finally two species were edible and ectomycorrhizal (Lycoperdon utriforme and Phlebopus marginatus).

Table 2 Macrofungi in Yenepoya Campus (June-November, 2016) (*: + occasional, ++ common, +++ abundant).

\begin{tabular}{|c|c|c|c|c|}
\hline Species & Habitat & Substrate & Occurrence* $^{*}$ & Remarks \\
\hline Agaricus sp. (Fig. 2a) & $\begin{array}{l}\text { Lawns of } \\
\text { playground and } \\
\text { gardens }\end{array}$ & Soil & June $(+)$ & Edible \\
\hline $\begin{array}{l}\text { Amylosporus campbellii (Berk.) } \\
\text { Ryvarden (Fig. 2b) }\end{array}$ & Bamboo thicket & Bamboo wood & $\begin{array}{l}\text { July-October } \\
(+++)\end{array}$ & $\begin{array}{l}\text { Edible and } \\
\text { medicinal }\end{array}$ \\
\hline $\begin{array}{l}\text { Auricularia auricula-judae (Bull.) } \\
\text { Quél (Fig. 2c) }\end{array}$ & $\begin{array}{l}\text { Acacia groves and } \\
\text { Bamboo thickets }\end{array}$ & $\begin{array}{l}\text { Acacia wood and } \\
\text { bamboo stubs }\end{array}$ & September $(+)$ & Edible \\
\hline $\begin{array}{l}\text { Chlorophyllum molybdites (G. } \\
\text { Mey.) Massee (Fig. 2d) }\end{array}$ & Medicinal garden & Soil & June $(+)$ & Poisonous \\
\hline Conocybe crispa (Longyear) & Lawns of & Soil & June and & \\
\hline Singer (Fig. 2e) & $\begin{array}{l}\text { playground and } \\
\text { gardens }\end{array}$ & & November $(++)$ & \\
\hline $\begin{array}{l}\text { Coprinus disseminatus (Pers.) } \\
\text { Gray (Fig. 2f) }\end{array}$ & $\begin{array}{l}\text { Medicinal and } \\
\text { horticulture } \\
\text { gardens }\end{array}$ & $\begin{array}{l}\text { Acacia wood and } \\
\text { stubs of Caryota } \\
\text { urens and banana } \\
\text { remains }\end{array}$ & September $(+)$ & Edible \\
\hline $\begin{array}{l}\text { Cystoagaricus trisulphuratus } \\
\text { (Berk.) Singer (Fig. 2g) }\end{array}$ & Horticulture garden & Soil & July (+) & \\
\hline $\begin{array}{l}\text { Dacryopinax spathularia } \\
\text { (Schwein.) G.W. Martin (Fig. 2h) }\end{array}$ & $\begin{array}{l}\text { Horticulture } \\
\text { gardens and } \\
\text { bamboo thicket }\end{array}$ & $\begin{array}{l}\text { Stubs of Acacia , } \\
\text { bamboo, coconut } \\
\text { and Terminalia }\end{array}$ & August $(++)$ & Edible \\
\hline $\begin{array}{l}\text { Daldinia concentrica (Bolton) } \\
\text { Ces. \& De Not. (Fig. 2i) }\end{array}$ & $\begin{array}{l}\text { Dumped wood and } \\
\text { bamboo thickets }\end{array}$ & $\begin{array}{l}\text { Stubs of Acacia } \\
\text { and bamboo }\end{array}$ & $\begin{array}{l}\text { July-November } \\
(+++)\end{array}$ & Medicinal \\
\hline $\begin{array}{l}\text { Ganoderma applanatum (Pers.) } \\
\text { Pat. (Fig. 2j) }\end{array}$ & $\begin{array}{l}\text { Areca plantations } \\
\text { and jack trees }\end{array}$ & $\begin{array}{l}\text { Stumps of Areca } \\
\text { and jack }\end{array}$ & $\begin{array}{l}\text { July-November } \\
(++)\end{array}$ & Medicinal \\
\hline $\begin{array}{l}\text { Ganoderma lucidum (Curtis) P. } \\
\text { Karst. (Fig. 2k) }\end{array}$ & Areca plantations & $\begin{array}{l}\text { Stumps of Areca } \\
\text { and jack }\end{array}$ & $\begin{array}{l}\text { July-November } \\
(++)\end{array}$ & Medicinal \\
\hline $\begin{array}{l}\text { Gymnopilus lateritius (Pat.) } \\
\text { Murrill (Fig. 2l) }\end{array}$ & Dumped wood & $\begin{array}{l}\text { Logs and stubs of } \\
\text { Acacia }\end{array}$ & August $(+)$ & Medicinal \\
\hline $\begin{array}{l}\text { Gymnopilus terricola K.A. } \\
\text { Thomas, Guzm.-Dáv. \& Manim. } \\
\text { (Fig. } 2 \mathrm{~m} \text { ) }\end{array}$ & $\begin{array}{l}\text { Lawns of } \\
\text { playground }\end{array}$ & Soil & June $(+)$ & \\
\hline Hexagonia tenuis Speg. (Fig. 2n) & Avenue trees & $\begin{array}{l}\text { Twigs of } \\
\text { gulmohar, } \\
\text { gooseberry and } \\
\text { Pongamia }\end{array}$ & $\begin{array}{l}\text { August-October } \\
(++)\end{array}$ & \\
\hline Ileodictyon gracile Berk. (Fig. 2o) & Bamboo thickets & $\begin{array}{l}\text { Humus, leaves } \\
\text { and twigs of } \\
\text { bamboo }\end{array}$ & $\begin{array}{l}\text { June-September } \\
(++)\end{array}$ & \\
\hline $\begin{array}{l}\text { Lentinus dicholamellatus Manim. } \\
\text { (Fig. 2p) }\end{array}$ & Dumped wood & $\begin{array}{l}\text { Logs and stubs of } \\
\text { cashew and } \\
\text { mango }\end{array}$ & August $(+)$ & $\begin{array}{l}\text { Edible and } \\
\text { medicinal }\end{array}$ \\
\hline
\end{tabular}


Table 2 (Contd.)

\begin{tabular}{|c|c|c|c|c|}
\hline Species & Habitat & Substrate & Occurrence* $^{*}$ & Remarks \\
\hline $\begin{array}{l}\text { Lentinus squarrosulus Mont. (Fig. } \\
\text { 3a) }\end{array}$ & Areca plantations & Logs of cashew & August $(+)$ & $\begin{array}{l}\text { Edible } \\
\text { and medicinal }\end{array}$ \\
\hline Lenzites betulina (L.) Fr. (Fig. 3b) & $\begin{array}{l}\text { Areca and banana } \\
\text { plantations }\end{array}$ & $\begin{array}{l}\text { Logs and stubs of } \\
\text { Acacia }\end{array}$ & $\begin{array}{l}\text { June-November } \\
(+++)\end{array}$ & Medicinal \\
\hline $\begin{array}{l}\text { Lycoperdon mammiforme Pers. } \\
\text { (Fig. 3c) }\end{array}$ & $\begin{array}{l}\text { Lawns of play } \\
\text { grounds and } \\
\text { gardens }\end{array}$ & Soil in lawns & June $(+)$ & \\
\hline $\begin{array}{l}\text { Lycoperdon utriforme Bull. (Fig. } \\
\text { 3d) }\end{array}$ & $\begin{array}{l}\text { Acacia groves and } \\
\text { Areca plantations }\end{array}$ & $\begin{array}{l}\text { Soils under } \\
\text { Acacia and mango } \\
\text { trees }\end{array}$ & June $(+)$ & $\begin{array}{l}\text { Edible and } \\
\text { ectomycorrhizal }\end{array}$ \\
\hline $\begin{array}{l}\text { Marasmiellus ignobilis (Berk. \& } \\
\text { Broome) Pegler (Fig. 3e) }\end{array}$ & Areca plantations & $\begin{array}{l}\text { Stubs and wood } \\
\text { of Areca }\end{array}$ & $\begin{array}{l}\text { July and } \\
\text { September }(+)\end{array}$ & \\
\hline $\begin{array}{l}\text { Marasmiellus stenophyllus } \\
\text { (Mont.) Singer (Fig. 3f) }\end{array}$ & $\begin{array}{l}\text { Areca and banana } \\
\text { plantations }\end{array}$ & $\begin{array}{l}\text { Logs of unknown } \\
\text { wood }\end{array}$ & $\begin{array}{l}\text { June-September } \\
(+++)\end{array}$ & \\
\hline $\begin{array}{l}\text { Marasmiellus subaurantiacus } \\
\text { (Berk. \& Broome) Pegler (Fig. } \\
\text { 3g) }\end{array}$ & Avenue trees & $\begin{array}{l}\text { Logs and bark of } \\
\text { Terminalia }\end{array}$ & $\begin{array}{l}\text { August and } \\
\text { September }(++)\end{array}$ & \\
\hline $\begin{array}{l}\text { Marasmius androsaceus (L.) Fr. } \\
\text { (Fig. 3h) }\end{array}$ & Areca plantations & $\begin{array}{l}\text { Humus and } \\
\text { rotting spathode } \\
\text { of Areca }\end{array}$ & $\begin{array}{l}\text { August and } \\
\text { September }(++)\end{array}$ & \\
\hline $\begin{array}{l}\text { Marasmius haematocephalus } \\
\text { (Mont.) Fr. (Fig. 3i) }\end{array}$ & Acacia groves & $\begin{array}{l}\text { Humus and leaf } \\
\text { /pod litter of } \\
\text { Acacia }\end{array}$ & $\begin{array}{l}\text { August and } \\
\text { September }(+)\end{array}$ & \\
\hline Marasmius sp. (Fig. 3j) & Acacia groves & $\begin{array}{l}\text { Leaves and pods } \\
\text { of Acacia }\end{array}$ & $\begin{array}{l}\text { September- } \\
\text { November }(++)\end{array}$ & \\
\hline $\begin{array}{l}\text { Microporus vernicipes (Berk.) } \\
\text { Kuntze (Fig. 3k) }\end{array}$ & $\begin{array}{l}\text { Acacia groves and } \\
\text { avenue trees }\end{array}$ & $\begin{array}{l}\text { Wood of Acacia } \\
\text { and Terminalia }\end{array}$ & September $(++)$ & \\
\hline Mycena rosea Gramberg (Fig. 3l) & Avenue trees & $\begin{array}{l}\text { Humus and } \\
\text { twig/leaf litter } \\
\text { below mango } \\
\text { trees }\end{array}$ & $\begin{array}{l}\text { August- } \\
\text { September }(+)\end{array}$ & \\
\hline $\begin{array}{l}\text { Omphalotus olearius (DE.) Singer } \\
\text { (Fig. } 3 \mathrm{~m} \text { ) }\end{array}$ & Avenue trees & $\begin{array}{l}\text { Soil below } \\
\text { Bougainvillea and } \\
\text { Garcinia }\end{array}$ & September $(+)$ & $\begin{array}{l}\text { Medicinal and } \\
\text { poisonous }\end{array}$ \\
\hline $\begin{array}{l}\text { Phallus atrovolvatus Kreisel \& } \\
\text { Calonge (Fig. 3n) }\end{array}$ & $\begin{array}{l}\text { Bamboo thickets } \\
\text { and coconut } \\
\text { plantations }\end{array}$ & $\begin{array}{l}\text { Soil in basins of } \\
\text { bamboo thickets } \\
\text { and coconut }\end{array}$ & June $(+)$ & \\
\hline Phallus duplicatus Bosc (Fig. 3o) & $\begin{array}{l}\text { Banana and } \\
\text { coconut plantations }\end{array}$ & $\begin{array}{l}\text { Soil and humus in } \\
\text { basins of banana } \\
\text { and coconut }\end{array}$ & June $(+)$ & \\
\hline $\begin{array}{l}\text { Phlebopus marginatus Watling \& } \\
\text { N. Gerg. (Fig. 3p) }\end{array}$ & Bamboo thickets & $\begin{array}{l}\text { Soil in bamboo } \\
\text { thickets }\end{array}$ & $\begin{array}{l}\text { October and } \\
\text { November }(++)\end{array}$ & $\begin{array}{l}\text { Edible and } \\
\text { ectomycorrhizal }\end{array}$ \\
\hline Polyporus sp. (Fig. 3q) & $\begin{array}{l}\text { Lawns of } \\
\text { playgrounds and } \\
\text { gardens }\end{array}$ & Soil and on cicada & $\begin{array}{l}\text { August and } \\
\text { September }(+)\end{array}$ & $\begin{array}{l}\text { Edible and } \\
\text { parasitic }\end{array}$ \\
\hline $\begin{array}{l}\text { Pycnoporus cinnabarinus (Jacq.) } \\
\text { P. Karst. (Fig. 3r) }\end{array}$ & Acacia groves & $\begin{array}{l}\text { Logs, stubs, } \\
\text { stumps of Acacia, } \\
\text { jack and } \\
\text { Terminalia }\end{array}$ & $\begin{array}{l}\text { August- } \\
\text { November }(++)\end{array}$ & $\begin{array}{l}\text { Medicinal and } \\
\text { yield pigment }\end{array}$ \\
\hline $\begin{array}{l}\text { Schizophyllum commune Fr. (Fig. } \\
\text { 3s) }\end{array}$ & $\begin{array}{l}\text { Acacia groves and } \\
\text { bamboo thickets }\end{array}$ & $\begin{array}{l}\text { Twigs, logs, stubs } \\
\text { and stumps of } \\
\text { Acacia, bamboo; } \\
\text { grass culms }\end{array}$ & $\begin{array}{l}\text { July-November } \\
(+++)\end{array}$ & Medicinal \\
\hline $\begin{array}{l}\text { Scutellinia setosa (Nees) Kuntze } \\
\text { (Fig. 2t) }\end{array}$ & $\begin{array}{l}\text { Areca, banana and } \\
\text { coconut plantations }\end{array}$ & $\begin{array}{l}\text { Remains of } \\
\text { coconut palms } \\
\text { and banana }\end{array}$ & September $(+)$ & \\
\hline
\end{tabular}


Table 2 (Contd.)

\begin{tabular}{|c|c|c|c|c|}
\hline Species & Habitat & Substrate & Occurrence* & Remarks \\
\hline $\begin{array}{l}\text { Termitomyces fuliginosus R. } \\
\text { Heim (Fig. 3u) }\end{array}$ & Termite mounds & Termite mound & July (+) & $\begin{array}{l}\text { Edible and } \\
\text { nutraceutical }\end{array}$ \\
\hline $\begin{array}{l}\text { Tetrapyrgos nigripes (Fr.) E. } \\
\text { Horak (Fig. 3v) }\end{array}$ & Acacia groves & $\begin{array}{l}\text { Twigs and pods of } \\
\text { Acacia }\end{array}$ & August (+) & \\
\hline $\begin{array}{l}\text { Volvariella bombycina (Schaeff.) } \\
\text { Singer (Fig. 3w) }\end{array}$ & Banana plantations & $\begin{array}{l}\text { Humus and leaves } \\
\text { of banana }\end{array}$ & July (+) & Edible \\
\hline $\begin{array}{l}\text { Xylaria multiplex (Kunze) Fr. } \\
\text { (Fig. } 3 \mathrm{x} \text { ) }\end{array}$ & $\begin{array}{l}\text { Gardens and } \\
\text { avenue trees }\end{array}$ & $\begin{array}{l}\text { Stubs of unknown } \\
\text { trees }\end{array}$ & $\begin{array}{l}\text { August- } \\
\text { November }(++)\end{array}$ & Medicinal \\
\hline
\end{tabular}
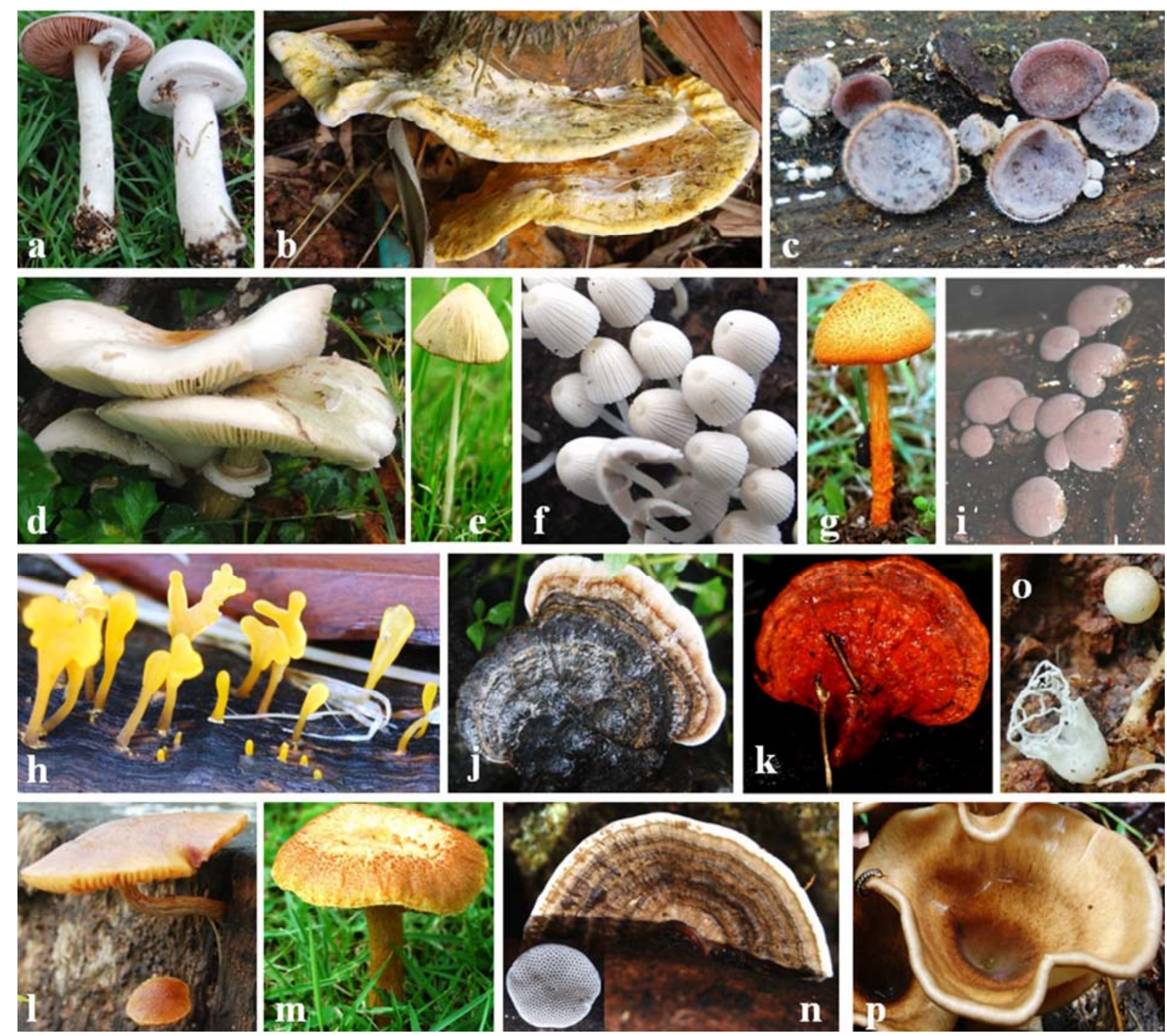

Fig. 2- Recorded taxa, for more detalis please check Table 2. Sporocarps of Agaricus sp. (a), Amylosporus campbellii (b), Auricularia auricula-judae (c), Chlorophyllum molybdites (d), Conocybe crispa (e), Coprinus disseminatus (f), Cystoagaricus trisulphuratus (g), Dacryopinax spathularia (h), Daldinia concentrica (i), Ganoderma applanatum (j), Ganoderma lucidum (k), Gymnopilus lateritius (l), Gymnopilus terricola (m), Hexagonia tenuis (n), Ileodictyon gracile (o) and Lentinus dicholamellatus (p). 

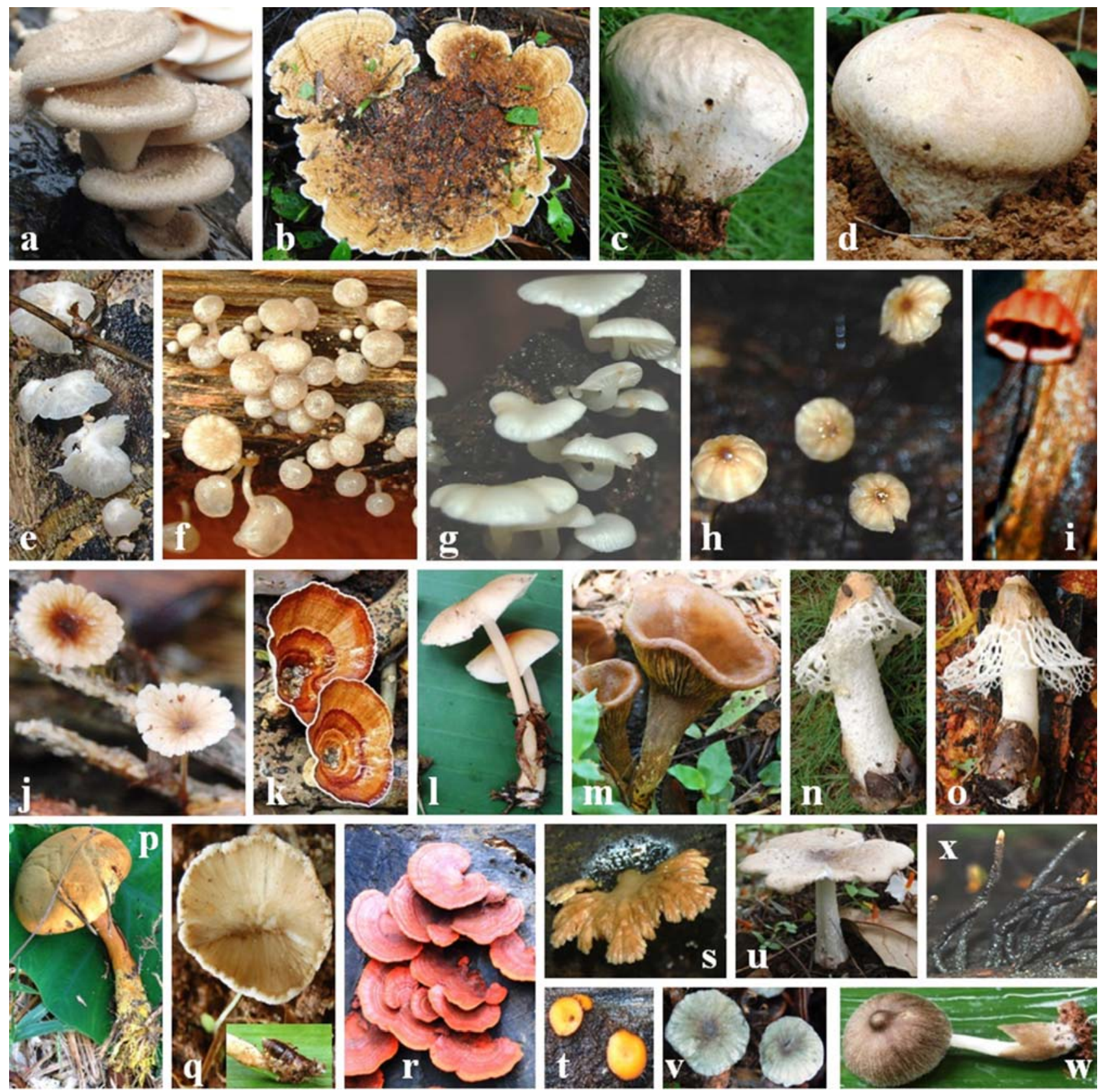

Fig. 3- Recorded taxa, for more detalis please check Table 2. Sporocarps of Lentinus squarrosulus(a), Lenzites betulina (b), Lycoperdon mammiforme (c), Lycoperdon utriforme (d), Marasmiellus ignobilis (e), Marasmiellus stenophyllus (f), Marasmiellus subaurantiacus (g), Marasmius androsaceus (h), Marasmius haematocephalus (i), Marsmius sp. (j), Microporus vernicipes (k), Mycena rosea (l), Omphalotus olearius (m), Phallus atrovolvatus (n), Phallus duplicatus (o), Phlebopus marginatus (p), Polyporus sp. (q), Pycnoporus cinnabarinus (r), Schizophyllum commune (s), Scutellinia setosa (t), Termitomyces fuliginosus (u), Tetrapyrgos nigripes (v), Volvariella bombycina (w) and Xylaria multiplex (x).

Macrofungi were confined to 10 different habitats (three plantations, bamboo thickets, Acacia grooves, gardens, avenue trees, lawns, wood dumps and termite mounds) (Fig. 5). Areca plantations yielded the highest record of 10 species, followed by bamboo thickets, gardens ( 9 spp. each) and Acacia groves (8 spp.), while rest of the habitats consists of 1-6 species. Areca plantations are common in the southwest coast; their floor remains wet almost throughout the 
year and this seems to be an excellent habitat for the cultivation of edible and medicinal macrofungi to generate additional income by farmers. Similarly, the bamboo thickets are also suitable habitat to raise desired macrofungi.

Macrofungi preferred three major substrates (soil, leaf litter and wood). Among them, woody substrates showed the highest of 22 species followed by soil (18 spp.) and leaf litter (7 spp.) (Fig. 6). The overlapping fungi were the highest of five species in soil and leaf litter (Ileodictyon gracile, Marasmius androsaceus, $M$. haematocephalus, Mycena rosea and Volvariella bombycina); two species preferred soil and wood (I. gracile and Mycena rosea); two species preferred wood and leaf litter (Coprinus disseminatus and I. gracile). The only fungus $I$. gracile was common to wood, soil and leaf litter. Among the substrates, Acacia wood was highly promising due to a yield of four edible and five medicinal fungi, while the bamboo wood yielded four edible and two medicinal fungi (see Table 2). This indicates that Acacia and bamboo woody material could be used for cultivation of economically viable macrofungi. Acacia and bamboo groves could also be maintained by selective felling, which leads to support macrofungi in woody debris as well as stubs. The same serve as suitable material for furniture as well as crafts, waste materials generated during wood processing will be suitable feedstock for the cultivation of desired macrofungi.

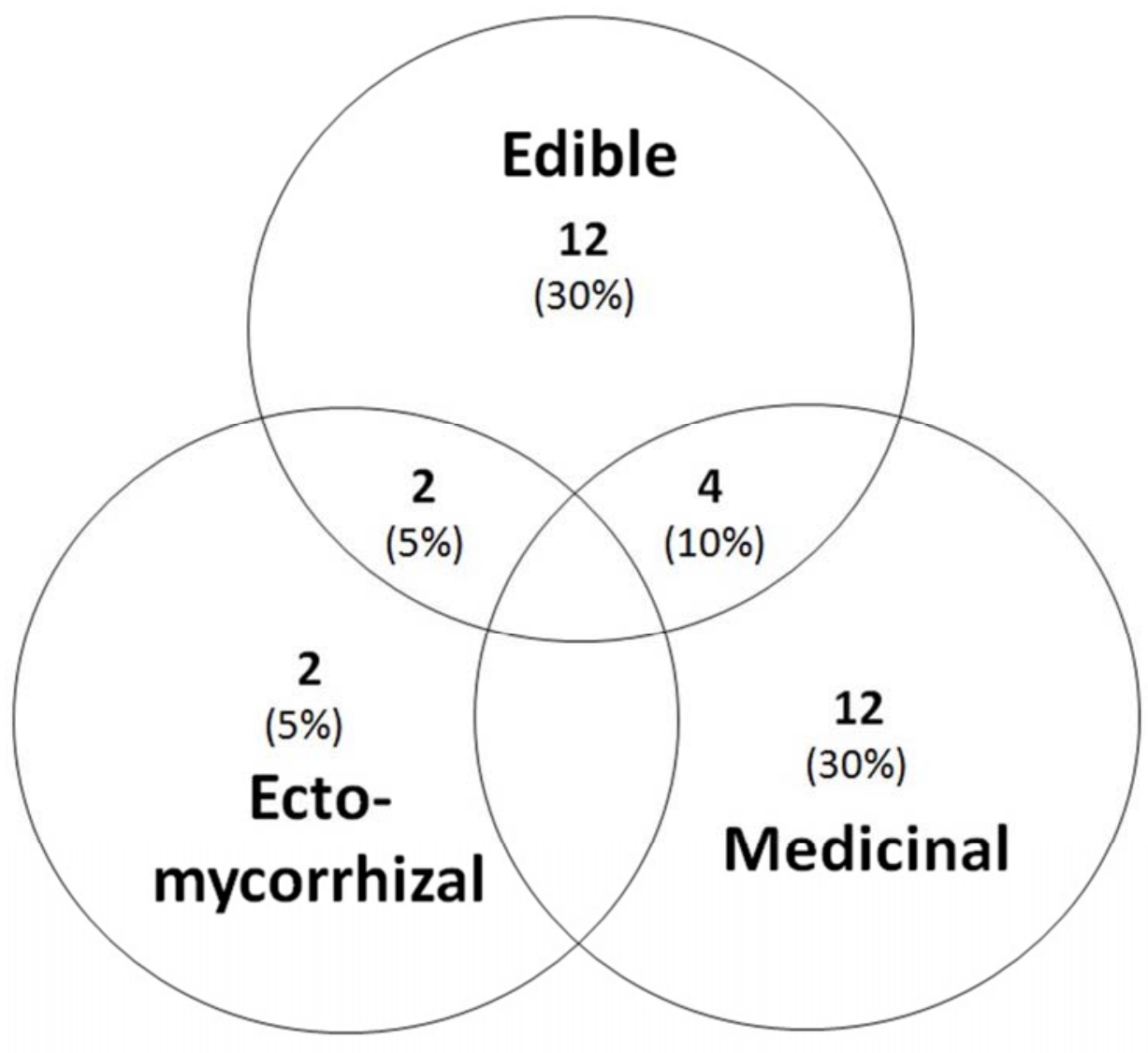

Fig. 4- Venn diagram showing distribution of edible, medicinal and ectomycorrhizal macrofungi. 


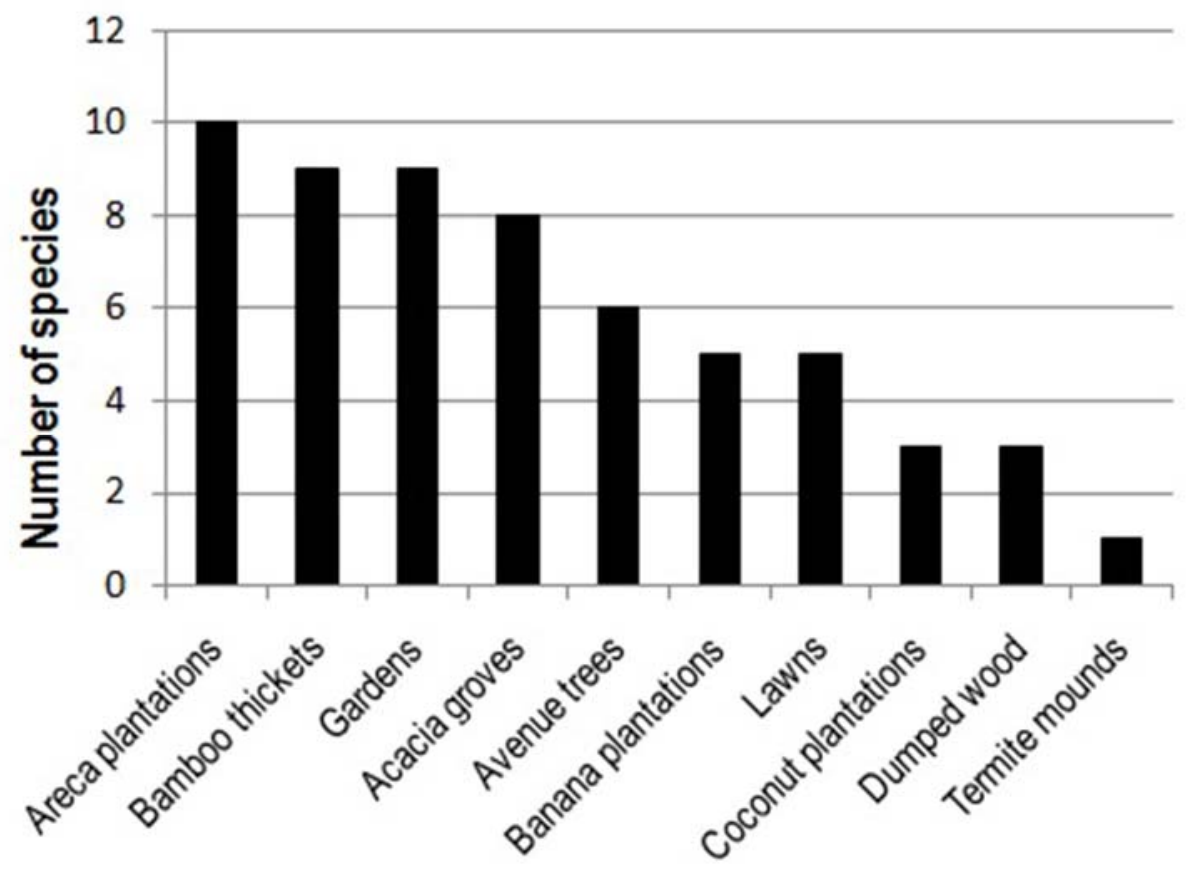

Fig. 5- Occurrence of macrofungi in different habitats.



Fig. 6- Venn diagram showing distribution and substrate preference of macrofungi.

Interaction of fungi with plants helps to develop mutualistic associations (e.g. mycorrhizal and endophytic). In the current study, two macrofungi were ectomycorrhizal with tree species Acacia, Areca, Mangifera (Lycoperdon utriforme) and Bambusa burmanica (Phlebopus marginatus). Cultivation of suitable host tree species supports a variety of ectomycorrhizal 
fungi (e.g. Artocarpus, Holigarna, Phyllanthus, Syzygium and Vateria) (Pavithra et al. 2015, 2016). In the YU Campus, many native trees like Artocarpus, Caryota, Garcinia, Mangifera and Terminalia have spread over supporting many macrofungi. One of the edible Polyporus sp. grew on the soil as well as infected the insect cicada (see inset Fig. 3q).

\section{Conclusions}

Assessment of soil, humus, leaf litter and woody debris in 10 habitats (three plantations, bamboo thickets, gardens, acacia groves, avenue trees, lawns, dumped wood and termite mounds) of Yenepoya Campus in southwestern India yielded 40 species of macrofungi (31 genera); they group twelve edible species, twelve medicinal elements, two ectomycorrhizal and only one entomophagous fungus. The occurrence of five species was abundant, 13 species were common and 22 species were occasional. Assessment of flora, fauna and fungi in a specific region helps to understand the status of habitat as healthy or regenerated or impoverished facilitating the follow-up biodiversity conservation measures for a healthy environment. This study demonstrated occurrence of interesting macrofungi in such institutional surroundings and also suggests possibilities of domestication of edible, medicinal and ectomycorrhizal fungi.

\section{Acknowledgements}

Authors are grateful to the authorities of Yenepoya (deemed to be University) for funding to carry out this research. We thank Prof. M. Abdul Rahiman for motivating us to carry out this study. We appreciate two referees for constructive suggestions to improve the manuscript.

\section{References}

Buczacki S. 2012. Collins Fungi Guide. Harper-Collins Publishers, London.

Cannon P.F. and Kirk P.M. 2007. Fungal Families of the World. CAB International, Wallingford.

Farook V.A., Khan S.S. and Manimohan P. 2013. A checklist of agarics (gilled mushrooms) of Kerala State. India. Mycosphere, 4: 97-131.

Ghate S.D. and Sridhar K.R. 2016a. Spatiotemporal diversity of macrofungi in the coastal sand dunes of Southwestern India. Mycosphere, 7: 458-472.

Ghate S.D. and Sridhar K.R. 2016b. Contribution to the knowledge on macrofungi in mangroves of the Southwest India. Plant Biosystems, 150: 977-986.

Jordan M. 2004. The Encyclopedia of Fungi of Britain and Europe. Francis Lincoln, London.

Karun N.C. and Sridhar K.R. 2014. A preliminary study on macrofungal diversity in an arboretum and three plantations of the southwest coast of India. Current Research in Environmental \& Applied Mycology, 4: 173-187

Karun N.C. and Sridhar K.R. 2016. Spatial and temporal diversity of macrofungi in the Western Ghat forests of India. Applied Ecology and Environmental Research, 14: 1-21.

Minter D.W. 2010. International society for fungal conservation. IMA Fungus, 1: 27-29.

Mohanan C. 2011. Macrofungi of Kerala. Kerala Forest Research Institute, Hand Book \# 27, Kerala, India.

Mueller G.M., Schmit J.P., Leacock P.R., Buyck B., Cifuentes J., Desjardin D.E., Halling R.E., Hjortstam K., Iturriaga T., Larsson K., Lodge D.J., May T.M., Minter D., Rajchenberg M., Redhead S.A., Ryvarden L., Trappe J.M., Walting R. and Wu Q. 2007. Global diversity and distribution of macrofungi. Biodiversity and Conservation, 16: 37-48.

Pavithra M., Greeshma A.A., Karun N.C. and Sridhar K.R. 2015. Observations on the Astraeus spp. of Southwestern India. Mycosphere, 6: 421-432.

Pavithra M., Sridhar K.R. and Greeshma A.A. 2017. Macrofungal inhabitants in botanical gardens of the south-western India. Journal of Threatened Taxa, 9: 9962-9970. 
Pavithra M., Sridhar K.R., Greeshma A.A. and Karun N.C. 2016. Spatial and temporal heterogeneity of macrofungi in the protected forests of Southwestern India. Journal of Agricultural Technology, 12: 105-124.

Pegler D. 1990. Kingfisher Field Guide to the Mushrooms and Toadstools of Britain and Europe. Kingfisher Publications, London.

Phillips R. 2006. Mushrooms. Pan Macmillan, London.

Ranadive K.R., Vaidya J.G., Jite P.K., Ranade V.D., Bhosale S.R., Rabba A.S., Hakimi M., Deshpande G.S., Rathod M.M., Forutan A., Kaur M., Naik-Vaidya C.D., Bapat G.S., Lamrood P. 2011. Checklist of Aphyllophorales from the Western Ghats of Maharashtra State, India. Mycosphere, 2: 91-114.

Senthilarasu G. 2014. Diversity of agarics (gilled mushrooms) of Maharashtra, India. Current Research in Environmental \& Applied Mycology, 4: 58-78.

Sridhar K.R. 2018. Highlights on the Macrofungi of South West Coast of Karnataka, India, International Journal of Life Sciences, A9: 37-42.

Swapna S., Abrar S. and Krishnappa M. 2008. Diversity of macrofungi in semi-evergreen and moist deciduous forest of Shimoga District, Karnataka, India. Journal of Mycology and Plant Pathology, 38: 21-26.

Tibuhwa D.D. 2012. Termitomyces species from Tanzania, their cultural properties and unequalled basidiospores. Journal of Biology and Life Science, 3: 140-159. 